\title{
Production of all male population of Indian catfish Heteropneustes fossilis (Bloch) by immersion and oral treatment of 17a-methyltestosterone
}

\author{
RAMANUJ CHAKRABORTY AND K. KARAL MARX \\ Department of Fisheries Biotechnology, Fisheries College and Research Institute, Tamil Nadu Fisheries University \\ Thoothukudi - 628 008, Tamil Nadu, India \\ e-mail:kkmarx@gmail.com
}

\begin{abstract}
Male dominated population of Indian catfish, Heteropneustes fossilis (Bloch) was produced through immersion and oral treatments with $17 \alpha$-methyltestosterone $(17 \alpha-\mathrm{MT})$. Two approaches were tested in immersion treatment. A group of fertilized eggs was exposed to a short duration treatment of $3 \mathrm{~h}$ with $17 \alpha$-MT at $0,50,100,150$ and $200 \mu \mathrm{gl}^{-1}$ and another group to a long duration treatment of 10 days at the same doses. A separate group of 3 days old hatchlings were fed with the hormone at $0,5,10,15$ and $20 \mathrm{mg} \mathrm{kg}^{-1}$ feed over a period of 28 days. Gonadal histology of the fishes 4 months post-treatment revealed significant $(\mathrm{p}<0.01)$ masculinising effect of $17 \alpha$-MT both in orally and immersion treated groups over the control. Among orally treated groups, most significant $(\mathrm{p}<0.01)$ effect was observed in the group that received hormone @ $5 \mathrm{mg} \mathrm{kg}^{-1}$ feed where $92.27 \%$ males were produced as compared to $43.05 \%$ males in the control group. Highest rate of masculinisation (97.56\%) was achieved in short term immersion in $100 \mu \mathrm{gl}^{-1}$ followed by $96.29 \%$ in $50 \mu \mathrm{gl}^{-1}$, whereas, in long term immersion, it was $92.59 \%$ in $50{\mu \mathrm{gl}^{-1}}^{1}$ followed by $92.41 \%$ in $100 \mu \mathrm{g} \mathrm{l}^{-1}$. There was no significant ( $>0.05$ ) difference between 50 and $100 \mu \mathrm{g} \mathrm{l}^{-1}$ concentrations in both short term and long term immersion treatments.
\end{abstract}

Keywords: Hatching, Heteropneustes fossilis, Indian catfish, Intersex, Sex reversal

Indian catfish Heteropneustes fossilis is widely distributed in several Asian countries such as India, Bangladesh, Pakistan, Nepal, Sri Lanka, Myanmar and Indonesia (Smith, 1945; Burgess, 1989). Though, this species has high market demand and sold in live condition, there is no farming of this species. The main bottleneck for farming of this species is the non-availability of seeds. In natural water bodies, females dominate over the males. Mookerjee et al. (1941) and Bhatt (1968) reported 1: 6 and 1: 2 proportions of males to females respectively in natural water bodies. Hence it may be assumed that a situation dealing with scarcity of males may stand as a barrier in commercial breeding programme and hence in turn may constraint seed production in captivity. Therefore, a study was conducted to produce male dominated populations through androgen (17 $\alpha$-methyl testosterone) induced sex reversal which may solve the above challenging problem and consequently can help to open a new horizon to raise the potential of $H$. fossilis as a candidate species for aquaculture. Haniffa et al. (2004) reported hormonal manipulation of sex in $H$. fossilis using $17 \alpha$-methyl testosterone and $17 \alpha$-ethynyl testosterone by immersion treatment.

The present study focused to determine the period that would be more sensitive in $H$. fossilis to the masculinising effect of the androgen, $17 \alpha-\mathrm{MT}$ and to determine the mode of treatment with effective dose/doses which result in greater degree of masculinisation. In addition, growth and survival rate were also evaluated to better understand the post-treatment-effects of the steroid.

Broodfishes of $H$. fossilis were maintained in round cement tanks of $2 \mathrm{~m}$ dia, $1 \mathrm{~m}$ height with a water depth of $60 \mathrm{~cm}$. Males and females were kept in separate tanks. Broodfishes were fed with formulated pellet feed with $33 \%$ protein. Fertilised eggs and hatchlings for the experiment were obtained by induced breeding of $H$. fossilis at $27 \pm 0.5^{\circ} \mathrm{C}$. The inducing hormone Ovaprim (Syndel Laboratories Ltd, Canada) was injected intramuscularly just below the dorsal fin and above the lateral line during late afternoon, only to female fish (@2.0 ml kg-1 body weight). After $10-13 \mathrm{~h}\left(27 \pm 0.5^{\circ} \mathrm{C}\right)$ of injection, females were stripped to collect the eggs. Males were sacrificed and testes were removed for the preparation of sperm suspension in Hank's Balanced Salt Solution (Hi Media, Mumbai, India).

Stock solution of the steroid hormone $17 \alpha$-methyltestosterone (Sigma, USA) was prepared by dissolving appropriate amount of the hormone in $95 \%$ ethanol. Each dose of $17 \alpha-\mathrm{MT}$ in immersion as well as dietary treatment were administered to three replicates; each containing 500 nos. of fertilised eggs/ 3 days old hatchlings respectively. 
In the short duration immersion treatment, aliquots of stock solution of $17 \alpha-\mathrm{MT}$ were added to plastic troughs holding 101 of freshwater. Compressed air was gently forced through an air stone to provide adequate oxygenation as well as mixing. Four groups of fertilised eggs $\left(20 \mathrm{~h}\right.$ after fertilisation at $27 \pm 0.5^{\circ} \mathrm{C}$ i.e., just before hatching) were immersed in $17 \alpha-\mathrm{MT}$ solutions for $3 \mathrm{~h}$ at concentrations viz., 50, 100, 150 and $200 \mu \mathrm{g} \mathrm{l}^{-1}$. In the control group, fertilised eggs were allowed to develop in pond water. The hatchlings were fed from day 3,5 and 7 onwards for thrice a day ad libitum on Artemia nauplii, chopped Chironomous larvae and hormone free commercial shrimp starter feed respectively. Shrimp starter feed was given two times a day at the rate of $5 \%$ body weight for 90 days.

In the second experiment (long duration immersion treatment), fertilised eggs were immersed in 17 $\alpha$-MT solution continuously for 10 days at concentrations of 50 , 100,150 and $200 \mu \mathrm{g}^{-1}$. In control group, the fertilised eggs were allowed to develop in pond water as done earlier. The hatchlings from this experiment were also fed in the same way and for the same duration as described in first experiment.

In the third experiment, masculinisation effect was studied through dietary administration of $17 \alpha-\mathrm{MT}$ in feed at various concentrations. Experimental feeds were prepared by spraying appropriate amount of diluted stock solution over commercial shrimp starter feed. The feed for control groups was prepared by spraying $95 \%$ ethanol. After ethanol evaporation at $50^{\circ} \mathrm{C}$ overnight, all the feeds were packed and stored at $4{ }^{\circ} \mathrm{C}$. Three days old hatchlings were fed with the hormone treated feed at concentrations of 5,10, 15 and $20 \mathrm{mg} \mathrm{kg}^{-1}$ feed, given thrice a day ad libitum for 28 days. After 28 days, the larvae were fed on hormone free commercial shrimp grower feed two times a day at the rate of $5 \%$ body weight for 90 days.

Experimental fishes from all the groups were grown in round cement tanks of $1 \mathrm{~m}$ dia and $0.3 \mathrm{~m}$ height holding water at depth of $0.25 \mathrm{~m}$ for a period of 4 months, so as to facilitate collection of gonad samples for histological examination to determine the sex.

Complete water exchange was done in each tank at monthly intervals and the post-treatment effect of the hormone on growth and survival was assessed and the quantity of feed adjusted. From each replicate, 25 randomly sampled fish were taken for recording the mean growth (body weight) of fish. Histological sections of the gonad samples were prepared and stained as per Humason (1972) and the slides were examined and photographed using a compound microscope fitted with camera (Nikon AFX-DX, Japan).
Histological preparations of gonadal samples from the control and treated groups were classified following Hurk et al. (1989); Gannam and Lovell (1991) and Piferrer et al. (1994). Analysis of data was carried out using two way ANOVA and Student's t-test when a significant difference occurred in the treatments. Chi-square $\left(\chi^{2}\right)$ test was used to determine whether the sex ratios differed from an expected 1:1 ratio (Snedecor and Cochran, 1967). Females and intersexes were combined into one category; so that, only fish that were observed as completely masculinised was recognised in the Chi-square test as affected by the treatment (Baker et al., 1988).

Dose standardisation of $17 \alpha-\mathrm{MT}$ for induction of sex reversal was accomplished after comparing the observations on the gonadal histology of treated and control groups of $H$. fossilis. Histological preparations of gonadal sections from the control and treated groups were classified into four viz., Type I (normal testis), Type II (affected testis), Type III (normal ovary) and Type IV (inter-sex).

Type I (Normal testis): Seminiferous tubules were found normal with lumen having less dense spermatozoa (Fig. 1)

Type II (Affected testis): Seminiferous tubules enlarged and lumen contains more dense spermatozoa (Fig. 2) as compared to control groups (Fig. 1).

Type III (Normal ovary): Vesicles surrounded by follicle cells (Fig. 3). Furthermore, some oocytes were also found with round nucleus containing several nucleoli. Previtellogenic oocytes had peripherally arranged nucleoli (Fig. 4.). Synchronous development of oocytes arranged in lamellar structure, presence of primary oocytes and formation of ovarian cavity were the features of a normal ovary (Fig. 4).

Type IV (Intersex): Spermatogonia intermingled with oocytes (Fig. 5). Female germ cells predominated over spermatogonia in the tissue. The gonads of intersexes showed absence of advanced stage of spermatogenesis. Ovotestes showed previtellogenic oocytes at the chromatin-nucleus stage (Fig. 6).

Evaluation of optimum dose of $17 \alpha$-MT for sex reversal was determined based on the masculinisation rate obtained through different modes of treatment. Immersion treatment and oral administration of hormone through feed resulted in varying degrees of masculinisation. Fish from all control groups exhibited gonads exclusively of either Type I or Type III (normal ovary) respectively at a proportion of 46.58 and $53.42 \%$ in short term immersion, 43.71 and $56.29 \%$ in long term immersion, and at a proportion of 43.05 and $56.95 \%$ in oral administration of $17 \alpha-\mathrm{MT}$ through feed. Chi-square 
test showed that the sex ratio did not deviate from an expected 1:1 ratio (Table 1).

The percentage of Type II gonad (affected testis) varied from 89.86 to $97.56 \%$. There was significant $(p<0.01)$ differences among different treatments. Fish from all treated groups had Type II gonads and apart from the above mentioned, a low proportion (2.44 - 10.13\%) of Type IV gonads was also found. No Type III gonads were observed in hormone treated groups. Chi-square test showed that in all the androgen treated groups, the proportion of Type II gonad was statistically significant $\left(\chi^{2}: \mathrm{p}<0.01\right)$ in comparison to corresponding control groups (Table 1). Highest percentage (97.56\%) of Type II gonad was found in the group treated with $100 \mu \mathrm{g} \mathrm{l}^{-1}$; $t$ test indicated that there was no significant difference between 50 and $100 \mu \mathrm{g} \mathrm{l}^{-1}$, indicating same effect on masculinisation.

Percentage of Type II gonad (affected testis) varied from 86.6 to $92.59 \%$ in long term immersion (Table 1). There was significant $(\mathrm{p}<0.01)$ difference among different treatments. Fish from all treated groups had Type II gonads and a low proportion (7.41$13.40 \%$ ) of Type IV gonad. No Type III gonads were observed in the androgen treated groups. Chi-square test showed that in all the androgen treated groups, the proportion of Type II gonad was statistically significant $\left(\chi^{2}: p<0.01\right)$ as compared to corresponding control groups (Table 1). Highest percentage (92.59\%) of Type II gonad was found in the group treated with $50 \mu \mathrm{g} \mathrm{l}^{-1} ; \mathrm{t}$ test indicated that there was no significant difference between 50 and $100 \mu \mathrm{g} \mathrm{l}^{-1}$ indicating similar effect on masculinisation.

In dietary administration, the percentage of Type II gonad varied from 82.22 to $92.27 \%$ (Table 1). There was significant $(\mathrm{p}<0.01)$ difference among different treatments. Fish from all treated groups had Type II gonads and a low proportion (7.74-17.78\%) of Type IV gonads (intersex) was also found. In groups that received $17 \alpha-$ MT at $20 \mathrm{mg} \mathrm{kg} \mathrm{kg}^{-1}$ feed, $1.22 \%$ of Type III gonad was observed. In all the androgen treated groups, the proportion of Type II gonad was statistically significant

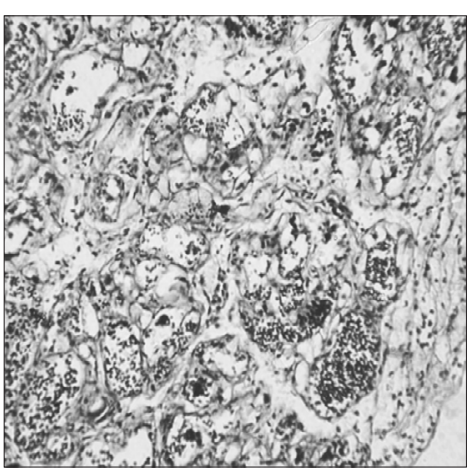

Fig. 1. Histological section of control male H. fossilis showing normal seminiferous tubules and less dense spermatozoa in the lumen (H\&E; x200)

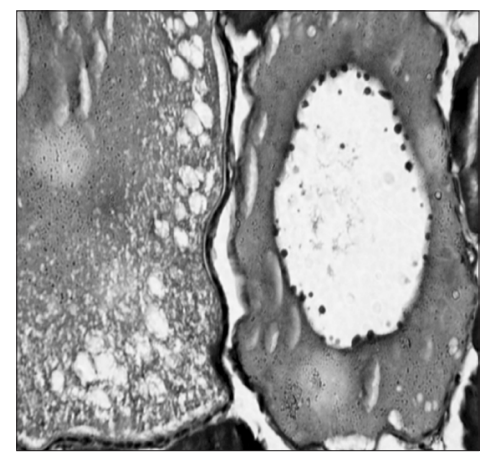

Fig. 4. Previtellogenic oocytes with nucleus containing peripherally arranged nucleoli in a normal female $H$. fossilis (H\&E; x400)

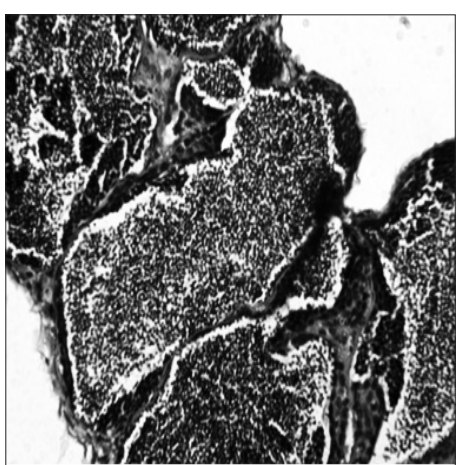

Fig. 2. Histological section of treated male H. fossilis showing enlarged seminiferous tubules and more dense spermatozoa in the lumen (H\&E; x400)

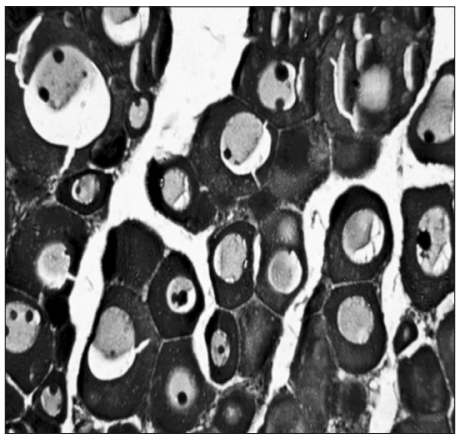

Fig. 5. Synchronous development of oocytes in the lamellae in a normal female $H$. fossilis $(\mathrm{H} \& \mathrm{E} ; \mathrm{x} 400)$

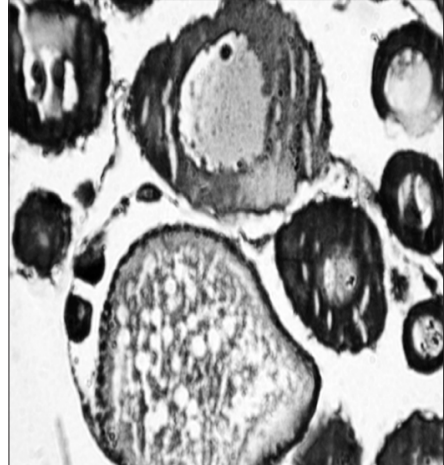

Fig. 3. Oocytes with nucleus, nucleoli and vesicles surrounded by follicle cells in a normal female $H$. fossilis (H\&E; x400)

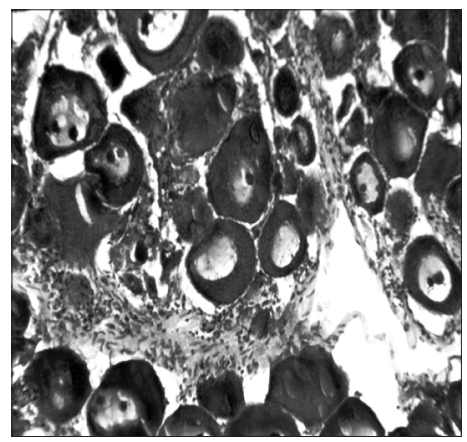

Fig. 6. Histological section of intersex gonad of $H$. fossilis showing presence of both spermatogonia and oocytes in the same gonad (H\&E; x400) 
Table 1. Details of sex proportions of $H$. fossilis in $17 \alpha$-methyltestosterone treatment

\begin{tabular}{|c|c|c|c|c|c|c|c|c|}
\hline $\begin{array}{l}\text { Experiment } \\
\text { no. }\end{array}$ & $\begin{array}{l}\text { Mode and } \\
\text { duration of } \\
\text { treatment }\end{array}$ & $\begin{array}{l}\text { Experimental } \\
\text { dose }\end{array}$ & $\begin{array}{l}\text { No. of fish } \\
\text { sexed }\end{array}$ & Males & Females & Intersex & $\begin{array}{l}\text { Sex ratio } \\
M: F^{\text {(a) }}\end{array}$ & $\begin{array}{l}\text { Chi-square } \\
\text { value }\end{array}$ \\
\hline $1 \mathrm{~A}$ & $\begin{array}{l}\text { Single short } \\
\text { term }(3 \mathrm{~h}) \\
\text { immersion } \\
\left(\mathrm{mg} \mathrm{l}^{-1}\right)\end{array}$ & $\begin{array}{l}50 \\
100 \\
150 \\
200 \\
0 \text { (Control) }\end{array}$ & $\begin{array}{l}350 \\
369 \\
365 \\
342 \\
365\end{array}$ & $\begin{array}{l}337(96.29) \\
360(97.56) \\
328(89.86) \\
321(93.80) \\
170(46.58)\end{array}$ & $\begin{array}{l}- \\
- \\
- \\
- \\
195(53.42)\end{array}$ & $\begin{array}{l}13(3.71) \\
9(2.44) \\
37(10.13) \\
21(6.14) \\
-\end{array}$ & $\begin{array}{l}1: 0.0386 \\
1: 0.025 \\
1: 0.1128 \\
1: 0.0654 \\
1: 1.1471\end{array}$ & $\begin{array}{l}300.2490^{* *} \\
334.0616^{* *} \\
232.1612^{* *} \\
216.771^{* *} \\
2.3538\end{array}$ \\
\hline 1B & $\begin{array}{l}\text { Long term } \\
\text { (10 days) } \\
\text { immersion } \\
\left(\mathrm{mg} \mathrm{l}^{-1}\right)\end{array}$ & $\begin{array}{l}50 \\
100 \\
150 \\
200 \\
0 \text { (Control) }\end{array}$ & $\begin{array}{l}297 \\
290 \\
291 \\
284 \\
286\end{array}$ & $\begin{array}{l}275(92.59) \\
268(92.41) \\
252(86.60) \\
258(87.32) \\
125(43.71)\end{array}$ & $\begin{array}{l}- \\
- \\
- \\
- \\
161(56.29)\end{array}$ & $\begin{array}{l}22(7.41) \\
22(7.59) \\
39(13.40) \\
36(12.68) \\
-\end{array}$ & $\begin{array}{l}1: 0.0800 \\
1: 0.0821 \\
1: 0.1548 \\
1: 0.01452 \\
1: 1.288\end{array}$ & $\begin{array}{l}215.7884^{* *} \\
209.8036^{* *} \\
157.1744^{* *} \\
159.3036^{* *} \\
2.9826\end{array}$ \\
\hline 2 & $\begin{array}{l}\text { Oral } \\
\text { administration } \\
\text { through feed } \\
\left(\mathrm{mg} \mathrm{kg}^{-1}\right) \\
\text { for } 28 \text { days }\end{array}$ & $\begin{array}{l}5 \\
10 \\
15 \\
20 \\
0 \text { (Control) }\end{array}$ & $\begin{array}{l}181 \\
186 \\
180 \\
164 \\
151\end{array}$ & $\begin{array}{l}167(92.27) \\
154(82.80) \\
148(82.22) \\
135(82.32) \\
65(43.05)\end{array}$ & $\begin{array}{l}- \\
- \\
- \\
2(1.22) \\
86(56.95)\end{array}$ & $\begin{array}{l}14(7.74) \\
32(17.20) \\
32(17.78) \\
27(16.46) \\
-\end{array}$ & $\begin{array}{l}1: 0.0838 \\
1: 0.2078 \\
1: 0.2162 \\
1: 0.2148 \\
1: 1.3231\end{array}$ & $\begin{array}{l}129.5642 * * \\
80.1874 * * \\
74.886^{* *} \\
69.1288^{* *} \\
4.73\end{array}$ \\
\hline
\end{tabular}

M: F - Males: Females

(a) Intersexes and females are combined in one category for Chi-square test. Figures in parentheses indicate percentage of above mentioned observations. ** Highly significant $(\mathrm{p}<0.01)$

$\left(\chi^{2}: \mathrm{p}<0.01\right)$ compared to their corresponding control groups (Table 1). Highest percentage (92.27\%) of Type II gonad was found in the group fed with androgen at $5 \mathrm{mg} \mathrm{kg}^{-1}$ feed and t-test showed that there was significant $(\mathrm{p}<0.01)$ difference between doses of 5 and $10 \mathrm{mg} \mathrm{kg}^{-1}$ feed.

$17 \alpha$-methyltestosterone has been found to be most effective among androgens in producing male dominated populations by sex reversal in several species of fish (Hunter and Donaldson, 1983). In the present study, administration of $17 \alpha$-MT significantly altered the sex ratio when compared to corresponding control groups by inducing sex reversal both in immersion and oral treatments, but did not induce sterility.

Both 50 and $100 \mu \mathrm{g} \mathrm{l}^{-1}$ concentrations in short term immersion were equally effective in masculinisation ( $>0.05$ ). Significant excess of males (89.86 to $97.56 \%$ ) over females in $H$. fossilis in this experiment was similar to the masculinising effect of $17 \alpha-\mathrm{MT}$ and 11ß-hydroxyandrostenedione reported by Hurk et al. (1989) in Clarias gariepinus, treated during day 28-56 after hatching at a concentration ranging from 30-300 $\mathrm{mg} \mathrm{l}^{-1}$. A higher percentage of males were observed by Haniffa et al. (2004) in H. fossilis by immersion in $100 \mathrm{mg} \mathrm{l}^{-1}$ of $17 \alpha-$ MT for $3 \mathrm{~h}$ after $20 \mathrm{~h}$ of fertilisation. Masculinisation of chinook salmon by immersion $\left(2 \mathrm{~h}\right.$ at $\left.200 \mathrm{mg} \mathrm{l}^{-1}\right)$ at the time of hatching produced $82-100 \%$ males (Baker et al., 1988) which supports the present investigation.

Both 50 and $100 \mu \mathrm{g} \mathrm{l}^{-1}$ concentrations in long term immersion were equally effective in masculinisation ( $p>0.05)$ with masculinisation rate in the range of 86.60 to $92.59 \%$. This observation was more or less similar to that of Karl Marx (2004) who reported a higher percentage of male population in C. gariepinus when 5 days old hatchlings were treated with $17 \alpha-M T$ for 5 days per week for 4 weeks at $100 \mathrm{mg} \mathrm{l}^{-1}$ concentration.

In the present investigation, oral administration of $17 \alpha$-MT resulted in 82.22 to $92.27 \%$ masulinisaton in H. fossilis. Highest percentage $(92.27 \%)$ of males were produced when fed with $17 \alpha-\mathrm{MT}$ at $5 \mathrm{mg} \mathrm{kg}^{-1}$ feed. The present study also is in agreement with Hendry et al. (2000) who produced $97-100 \%$ male dominated population of Atlantic halibut (Hippoglossus hippoglossus) when the post-larvae were fed with artificial pellets supplemented with $17 \alpha$-methyldihydrotestosterone at 1 and $5 \mathrm{ppm}$.

Hunter and Donaldson (1983) reported that treatment with androgens have been found to induce intersexuality (hermaphroditism) in guppy, rainbow tout, chinook salmon, masu salmon, Atlantic salmon and grass carp. Present investigation revealed the presence of intesex population in varying degrees from the $17 \alpha-M T$ treated groups of $H$. fossilis. Intersex population was found at 
a low proportion viz., 2.44 to $10.13 \%, 7.41$ to $13.40 \%$ and 7.74 to $17.78 \%$ in short term immersion, long term immersion and oral route of treatment respectively. Moreover, higher doses except the extreme values of $17 \alpha-\mathrm{MT}$ in both long term immersion and oral routes gave comparatively higher percentage of intersex populations compared to the lower doses. Similarly, Nagy et al. (1981) observed intersex individuals (8.4 to $38.5 \%$ ) in $17 \alpha-\mathrm{MT}$ fed gynogenetic females of Cyprinus carpio.

Androgen administration has been reported to induce paradoxical feminisation in fishes like C. gariepinus (Hurk et al., 1989; Karl Marx, 2004). However, in the present study, paradoxical feminisation effect of androgen was not observed which suggests that the doses and durations of treatment might not be sufficiently higher enough for inducing the feminising effect in treated H. fossilis.

High degree of masculinisation in $H$. fossilis could be achieved either by single short term immersion around the time of hatching for $3 \mathrm{~h}$ at $100 \mathrm{mg} \mathrm{l}^{-1}$ or by long term immersion for 10 days at $50 \mathrm{mg} \mathrm{l}^{-1}$, or by oral administration of 3 days old hatchlings with $17 \alpha-\mathrm{MT}$ at $5 \mathrm{mg} \mathrm{kg}^{-1}$ feed for 28 days. Though, $100 \%$ masculinisation was not achieved in the present study, the results demonstrated significant excess of males over the control groups following different modes of treatments. Based on the results of the present study, it may be concluded that $H$. fossilis is amenable for endocrine mediated sex change by androgen treatment, which may be applied at around the time of hatching by immersion and by oral administration of 17a-MT starting from day 3 post-hatch up to 28 days

\section{References}

Baker, I. J., Solar, I. I. and Donaldson, E. M. 1988. Masculinisation of chinook salmon (Oncorhynchus tshawytscha) by immersion treatments using $17 \alpha$-methyltestosterone around the time of hatching. Aquaculture, 72: 359-367.

Bhatt, V. S. 1968. Studies on the biology of some freshwater fishes. Part VII. Heteropneustes fossilis (Bloch). Indian J. Fish., 15(1\&2): 99-115.

Burgess, W. E. 1989. An Atlas of freshwater and marine water catfishes - a preliminary survey of the Siluriformes. T. F. H. Publications, Inc., 784 pp.

Gannam, A. L. and Lovell, R. T. 1991. Effects of feeding $17 \alpha$-methyltestosterone, 11-ketotestosterone, 17ß-estradiol, and 3, 5, 3' triiodothyronine to Channel catfish, Ictalurus punctatus. Aquaculture, 92: 377-388.

Haniffa, M. A., Sridhar, S. and Nagarajan, M. 2004. Hormonal manipulation of sex in stinging catfish Heteropneustes fossilis (Bloch). Curr. Sci., 86(7): 1012-1017.

Hendry, C. I., Robichaud, D. J. M. and Benfey, T. J. 2000. Hormonal sex reversal of Atlantic halibut (Hippoglossus hippoglossus, L.). In: Hendry, C. I. and Gladdery, S. E. M. C. (Eds.), Proceedings of the $17^{\text {th }}$ Annual meetings of the Aquacultural Association of Canada, Moncton, Canada, p. 41-44.

Humason, G. L. 1972. Animal tissue techniques, $3^{\text {rd }}$ edn. Freeman, W. H. and Company, San Francisco, 641 pp.

Hunter, G. A. and Donaldson, E. M. 1983. Hormonal sex control and its application to fish culture. In: Hoar, W. S., Randall, D. J. and Brett, J. R. (Eds.), Fish physiology IXB, Academic Press, New York, p. 223-291.

Hurk, R. V. D., Richter, C. J. J. and Dommerholt, J. J. 1989. Effects of $17 \alpha$-methyltestosterone and 11ß-hydroxyandrostenedione on gonadal differentiation in the African catfish, Clarias gariepinus. Aquaculture, 83: 179-191.

KarlMarx, K.2004.Studies on the genetic improvementtechniques in air-breathing catfish, Clarias gariepinus (Burchell, 1822). $\mathrm{Ph}$. D. Thesis. Manonmaniam Sundaranar University, Alwarkurichi, India, 205 pp.

Mookerjee, H. K., Majumdar, S. R. and Das Gupta, B.1941. On the nature of urinogential papillae of Clarias batrachus (Linn.) and Heteropneustes fossilis (Bloch). Indian J. Vet. Sci., 2(4): 334-326.

Nagy, A., Bercony, M. and Csanyi, V. 1981. Sex reversal in carp (Cyprinus carpio) by oral administration of methyltestosterone. Can. J. Aquat. Sci., 38: 725-728.

Piferrer, F., Carrillo, M., Zanuy, S., Solar, I. I. and Donaldson, E.M. 1994. Induction of sterility in coho salmon (Oncorhynchus kisutch) by androgen immersion before first feeding. Aquaculture, 119: 409-423.

Smith, H. M. 1945. The freshwater fishes of Sian or Thailand. United States National Museum Bulletin, 188, Smithsonian Institute, Washington, D. C., 622 pp.

Snedecor, G. W. and Cochran, W. G. 1967. Statistical methods. Oxford and IBH Publishing Co., New Delhi, 593 pp. 